\title{
Determination of Potential Landfill Site in Tarkwa Area Using Multi-Criteria GIS, Geophysical and Geotechnical Evaluation
}

\author{
Asare Asante-Annor, Samuel Asare Konadu, Ebenezer Ansah \\ Geological Engineering Department, University of Mines and Technology, Tarkwa, Ghana \\ Email: aasante-annor@umat.edu.gh
}

How to cite this paper: Asante-Annor, A., Konadu, S.A. and Ansah, E. (2018) Determination of Potential Landfill Site in Tarkwa Area Using Multi-Criteria GIS, Geophysical and Geotechnical Evaluation. Journal of Geoscience and Environment Protection, 6, 1-27.

https://doi.org/10.4236/gep.2018.610001

Received: August 25, 2018

Accepted: September 27, 2018

Published: September 30, 2018

Copyright $\odot 2018$ by authors and Scientific Research Publishing Inc. This work is licensed under the Creative Commons Attribution International License (CC BY 4.0).

http://creativecommons.org/licenses/by/4.0/

\begin{abstract}
A 24-acre land at Aboso serves as the site where municipal solid waste from Tarkwa and its environs are openly dumped. Evaluation of the suitability of this existing landfill site for the construction of an engineered landfill was determined. Reconnaissance survey, structural mapping, determination of depth to groundwater, geotechnical site investigation as well as socio-economic indicators showed that the existing landfill site is not suitable for an engineered landfill construction. A multi-criteria GIS model was used to select an alternative suitable area for the construction of an engineered landfill. The multicriteria GIS modelling identified fourteen (14) suitable areas for the siting of landfill in the Tarkwa area. A site located in Domeabra was chosen due to its proximity to the neighbouring communities of Tarkwa, Nsuta and Aboso. The suitability of the proposed site in Domeabra was assessed using geotechnical and geophysical methods. The geotechnical methods included the testing of soil properties such as moisture content, particle size distribution, Atterberg limit, bulk density, specific gravity, and compactibility. The soils at Domeabra site are predominantly gravel and sand, well graded with gradual increase in clay content with depth and good moisture content (less than $30 \%)$. The gravel and sandy soils have good to excellent shear strength and work ability. The soils in Domeabra have suitable dry density $(1.3-2.1$ $\left.\mathrm{Mg} / \mathrm{m}^{3}\right)$, bulk density $\left(1.7-2.5 \mathrm{Mg} / \mathrm{m}^{3}\right)$ and specific gravity $(2.2-2.9)$ for landfill construction. The geophysical method involved the use of seismic refraction tomography. The geophysical survey showed that the site is made up of four layers namely the top soil $(0.5-2 \mathrm{~m})$, weathered material $(5-15 \mathrm{~m})$, saturated material $(10-15 \mathrm{~m})$ and fresh rock. The water table occurs at a depth of 12 to $15 \mathrm{~m}$. The proposed area in Domeabra based on the geophysical and geotechnical investigations is suitable for the construction of engineered landfill.
\end{abstract}




\section{Keywords}

Landfill Site, Multi-Criteria GIS, Seismic Refraction Tomography, Geotechnical Site Investigation, Tarkwa Area

\section{Introduction}

Waste generation is on the ascendancy in both developing and developed countries. With increase in the global population and the rising demand for food and other essentials, there has been a rise in the amount of waste being generated daily by each household [1]. Management of waste has become an important issue for policy makers and town planners. The huge waste generated has necessitated the siting and construction of engineered landfill sites where municipal solid waste (MSW) are dumped. MSW consists of daily items including recyclable materials like paper, plastics, textiles, metals, glass, yard wastes; organic materials like food; inorganic materials such as dirt, a small amount of construction wastes; and miscellaneous other materials [2]. There are however challenges with MSW management; the economical and infrastructural constraints, including unavailability of land for safe waste disposal, and lack of awareness and fear at all levels restrain progress resulting in inefficient, unsafe urban solid waste management [3]. Countries in the developing world, including Ghana, continue to struggle with basic collection and disposal, and its implicit cost [4] [5]. Improper disposal of waste may lead to contamination of both surface and groundwater, soils and affecting plants, animals and microorganisms. Waste generation has close relationships with population increase, urbanisation and affluence [6]. Uncontrolled dumping of wastes at the outskirts of towns and cities has created overflowing landfills, which have environmental impacts in the form of pollution to soil, groundwater, air, and contribute to global warming [7]. Several studies conducted to examine the health and environmental effects arising from waste dumps showed that a link exists between the two [8] [9] [10] [11] [12].

In Ghana, waste disposal and location of landfills are a major problem. Typically, most urban landscapes are characterised by mountains of uncollected garbage, gutters choked with waste, open reservoirs that appear to be a little more than toxic pools of liquid waste and beaches strewn with plastic garbage [13]. Kusi et al. [14] states that landfills are sited close to water bodies, highways and schools. He identified that most communities in municipalities and districts resort to open dumps for disposing their Municipal Solid Waste. Although their research identified three (3) landfill types in operation in Ghana namely; open dumps, improved dumps and engineered landfills; the predominance of open dumps is because it is convenient and less expensive to operate compared to engineered landfills which are operated in Metropolitan areas [14]. With the increase in the use of plastics, this pollution has led to the alteration of overburden 
soil layers. The problem is acute in cities with large population than in rural communities as observed by Onibokum and Kumuyi [15]. The ominous environmental, social and health impact of this neglect is greatest among those living in the low-income and peri-urban settlements where access to collection routes is a challenge.

The Ghana landfill guidelines published by the EPA is an attempt to promote and help upgrade landfills, initially by improving site selection, waste compaction and drainage resulting in high density aerobic landfills and culminating in achieving operation of sanitary landfills by 2020 . However, slow this process might be, there is evidence to show that progress is being made to achieve these targets [16]. Tarkwa is a mining town with four major mining companies and University of Mines and Technology.

Currently, there is no engineered landfill site for the waste generated in Tarkwa, Nsuta, Aboso and Domeabra; however, there is an existing open landfill serving Tarkwa and its environs at Aboso (Figure 1(a)). Reconnaissance survey carried out at the current Aboso site showed that more than $80 \%$ of the soil samples from the existing open landfill site are coarse. The soil particles have less than $10 \%$ fines and averagely classified as silt with low plasticity. The average groundwater level from wells located within $1 \mathrm{~km}$ radius was determined to be $0.81 \mathrm{~m}$. Leachate from the open landfill at Aboso was observed to have been mixed with surface runoff which flows to a stream $10 \mathrm{~m}$ away from the landfill as shown in Figure 1(b). A construction project for a community day Senior High School was observed in $100 \mathrm{~m}$ south west of the landfill site. A penetrating quartz vein located $20 \mathrm{~m}$ east of the landfill site indicates that the site may be structurally deformed. The presence of structures such as shear, veins and faults were mapped in an excavation (small scale mine pit) located $20 \mathrm{~m}$ north-east of the landfill. The dip direction of the structural discontinuities on a regional scale range from $085^{\circ}$ to $160^{\circ}$ with a maximum concentration of dip angle ranging from $75^{\circ}$ to $85^{\circ}$.

The EPA [17] Ghana landfill guidelines (Table 1) states that, a site is disqualified to be used as a landfill if the area is close to significant surface water bodies, $300 \mathrm{~m}$ for ponds, lakes and dams, and $90 \mathrm{~m}$ for rivers. The guidelines further stress that areas characterised by flat gradients $(<2 \%)$, shallow or emergent groundwater (springs and seepages) where enough unsaturated zone separating the waste body and the groundwater would not be possible is disqualified for landfill. Additionally, unstable areas including fault zones, seismic zones and areas with mining pits where subsidence are likely are not considered for landfills. The existing site at Abosois thus, unsuitable for the construction of an engineered landfill. There the need to identify an alternative site which could be used for the construction of an engineered landfill serving Tarkwa and its environs.

Identifying suitable landfill sites is very difficult since one must consider the future effect of the waste on the environment, meeting regulatory standards as 


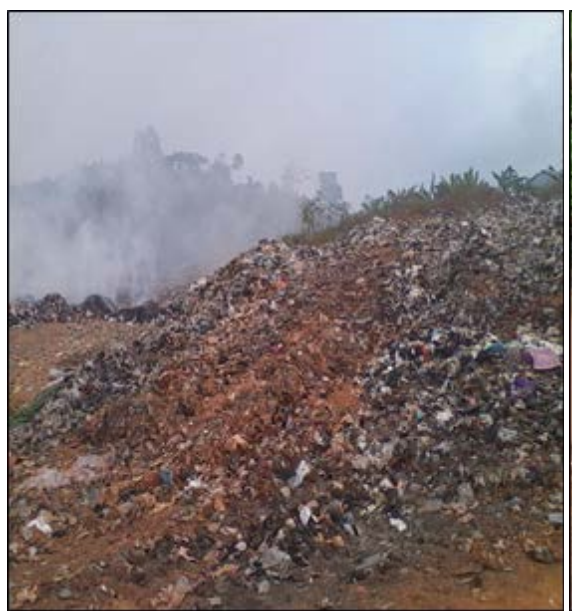

(a)

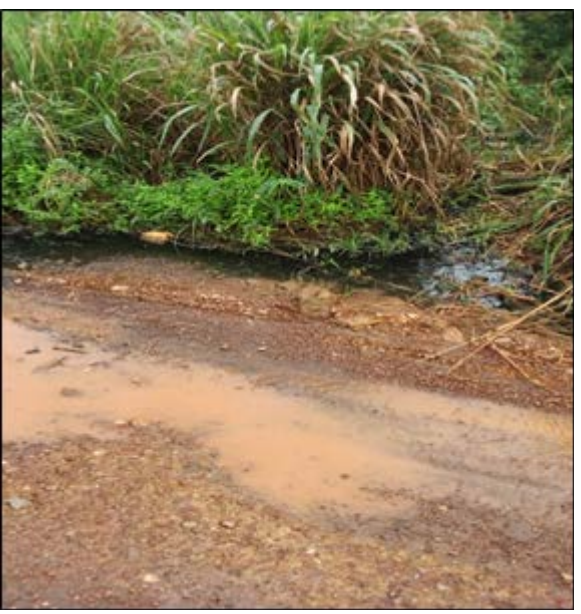

(b)

Figure 1. (a) Exsting open landfill site at Aboso and (b) surface runoff mixed with leachate.

Table 1. Criteria for the selection of a suitable landfill site.

\begin{tabular}{|c|c|c|}
\hline Criteria & Buffer Zone & Reason for Buffer Distance \\
\hline Wetlands & $500 \mathrm{~m}$ & $\begin{array}{l}\text { To help prevent the creation of breeding grounds for insects } \\
\text { like mosquitoes which transmits the malaria parasite }\end{array}$ \\
\hline Roads & $300 \mathrm{~m}$ & $\begin{array}{l}\text { To prevent expensive cost of constructing connecting } \\
\text { roads to the landfill site }\end{array}$ \\
\hline Railway & $300 \mathrm{~m}$ & $\begin{array}{l}\text { To prevent the habitants from being involved } \\
\text { in any accident which can be caused by the train as } \\
\text { they go out to dump their waste }\end{array}$ \\
\hline Built-up areas & $300 \mathrm{~m}$ & $\begin{array}{l}\text { To help minimise the health hazards caused } \\
\text { by landfills on inhabitants }\end{array}$ \\
\hline Surface water & $300 \mathrm{~m}$ & To prevent leachate seeping in the surface water \\
\hline
\end{tabular}

Modified after EPA [17].

well as geophysical, geotechnical and other parameters. This study seeks to determine a suitable landfill site for Tarkwa and its environs using multi-criteria GIS, Geophysical and Geotechnical evaluation approach.

\subsection{Location and Physiography}

The study area consisted of Tarkwa, Nsuta, Aboso and Domeabra as shown in Figure 2. Tarkwa is the capital of Tarkwa-Nsuaem Municipal, a district in the Western Region southwest of Southern Ghana. Aboso is a town located in the Prestea-Huni-Valley District of the Western Region of Ghana. It is located between Tarkwa and Huni-Valley along the Tarkwa-Agyempoma road and approximately $9.9 \mathrm{~km}$ and $13.7 \mathrm{~km}$ away from these towns respectively. Domeabra is a village within the Tarkwa-Nsuaem municipality of the western region of Ghana. It is $9.7 \mathrm{~km}$ from Tarkwa and $4.9 \mathrm{~km}$ from Nsuta and is accessed by road from Tarkwa. 


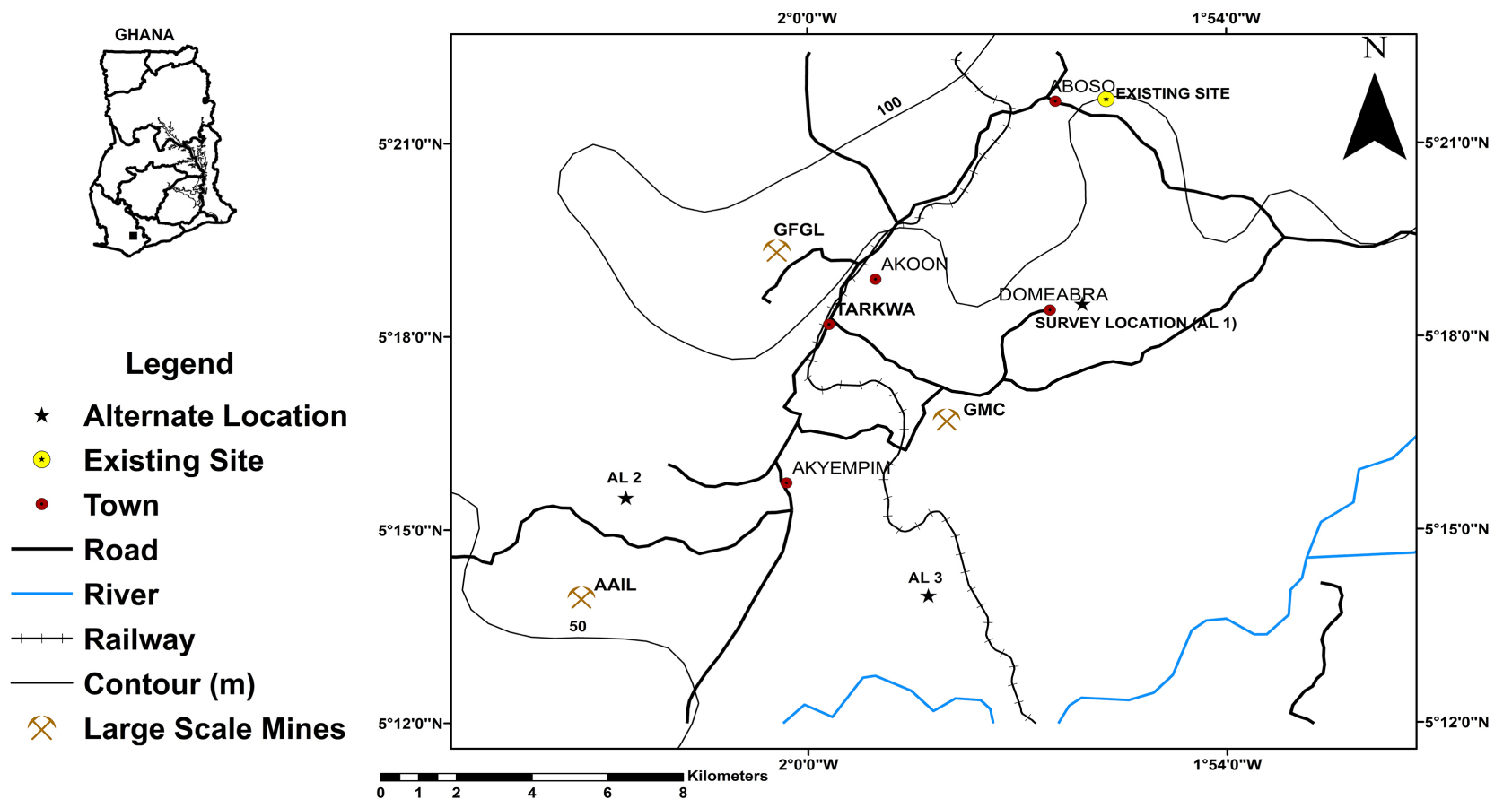

Figure 2. Study area map showing existing landfill, alternate suitable sites and survey location [18].

\subsection{Soils and Geology}

There are mainly two types of soil in the Tarkwa-Prestea area, the forest oxysols in the south and the forest ochrosol-oxysol integrates in the north [19]. The forest oxysols are porous, well drained, and generally loamy brown to orange. Due to the heavy and plentiful rainfalls in the south, a high degree of leaching and reduction of calcium, magnesium and other nutrients have occurred in the soil. This has made the soilacidic. The forest ochrosol-oxysol integrated is an intermediate between the forest oxysols and the forest orhrosol. It contains more of its nutrients and is therefore more alkaline then the forest oxysols in the south [19].

The study area (Figure 3) falls within the BirimianMetavolcanic rocks. The Birimian rocks form an extensive southernmost approximately two-thirds of the estimated $4.5 \times 10^{6} \mathrm{~km}^{2}$ area of the Precambrian West African Craton (WAC) [20]. It is bounded to the west by the Pan-African mobile zone of the Mauritanides-Rokellides, to the north and the east by the transgressive cover of the Phanerozoic Taoudeni and Volta basins respectively, stretching over Côte d' Ivoire, Ghana, Mali, Burkina Faso, Guinea, Liberia, Sierra Leone and west Niger. Attoh et al. [20] stated that these rocks record the most extensive episode of continental crust formation in the early part of the Proterozoic. The WAC furthermore comprises a western domain consisting essentially of Achaean rocks of Liberian age (3.0 - $2.5 \mathrm{Ga})[21]$.

The Birimian rocks fall within Paleoproterozoic terrane which is characterised by narrow sedimentary basins and a dominantly linear arcuate bimodal volcanic and volcano-sedimentary with mostly felsic to intermediate protolith 
[22]. Available data suggest that the rocks formed during one of the most rapid (early Proterozoic) continental crust-forming events in the world [23]. The stratigraphic subdivision of the Birimian rocks has been a matter of considerable debate since the middle of the last century. The Birimian rocks were overlain dominantly by clastic Tarkwaian rocks and were, in addition, extensively intruded by granitoids during the Eburnian Orogeny [24]. The latter is predominantly mafic volcanics; with pyroclastics, hypabyssal intrusives, phyllites and greywackes as common constituents. The former is characterised by a predominance of immature or volcaniclastic sediments, including argillites, tuffs and greywackes [25].

The term "Birimian" was introduced by Kitson [26] to describe rocks from the valley of the River Birim in Ghana. The stratigraphy of the Birimian is a subject of substantial debate with proposal of three distinctly different subdivisions. In numerous studies, the volcanic formations are considered to be younger than the sedimentary sequences [27]. Leubeet al. [28] suggested that the volcanic sequences and sedimentary basins are contemporaneous lateral facies equivalents, while others place the basalts and andesites at the base, overlain by flysch-type sedimentary sequences [29]. The latter view was also shared by Milesi et al. [30]. Leube et al. [28] are of the view that penecontemporaneous deposition of the tholeiitic flows and the various sedimentary rocks is indicated by a transition from volcanic rocks into sedimentary rocks along strike and interbedding between the two rock types.

\subsection{Hydrology and Hydrogeology}

The Birimian and Tarkwaian rocks that underlie the area are largely crystalline and inherently impermeable, unless fractured or weathered. Groundwater occurrence is therefore attributed with the development of secondary permeability and porosity. According to Kortatsi [31], the zones of secondary permeability are often discrete and irregular and occur as fractures, faults, lithological contacts and zones of deep weathering. Groundwater in the area is acknowledged to occur in two distinct hydraulically connected aquifer system; an upper weathered zone aquifer and a deeper un-weathered aquifer or fractured zones and dyke contacts [25].

The weathered zone aquifer is generally phreatic, and the principal groundwater flow occurs where relic's quartz veins are more abundant. The regolith is generally dominated by clay and silt, rendering the aquifer highly porous, with high storage, but low permeability. Thus, the aquifers here are either un-confined or semi-confined, depending on the clay and silt proportion. Aquifers are recharged by direct infiltration of precipitation through brecciated zones and the weathered outcrop [31]. Groundwater recharge and actual evapotranspiration have been estimated at between $11 \%-17 \%$ and $54 \%$ respectively of annual rainfall [32] with the average borehole yield ranging from $2.7-12.7 \mathrm{~m}^{3} / \mathrm{h}$ [33]. 


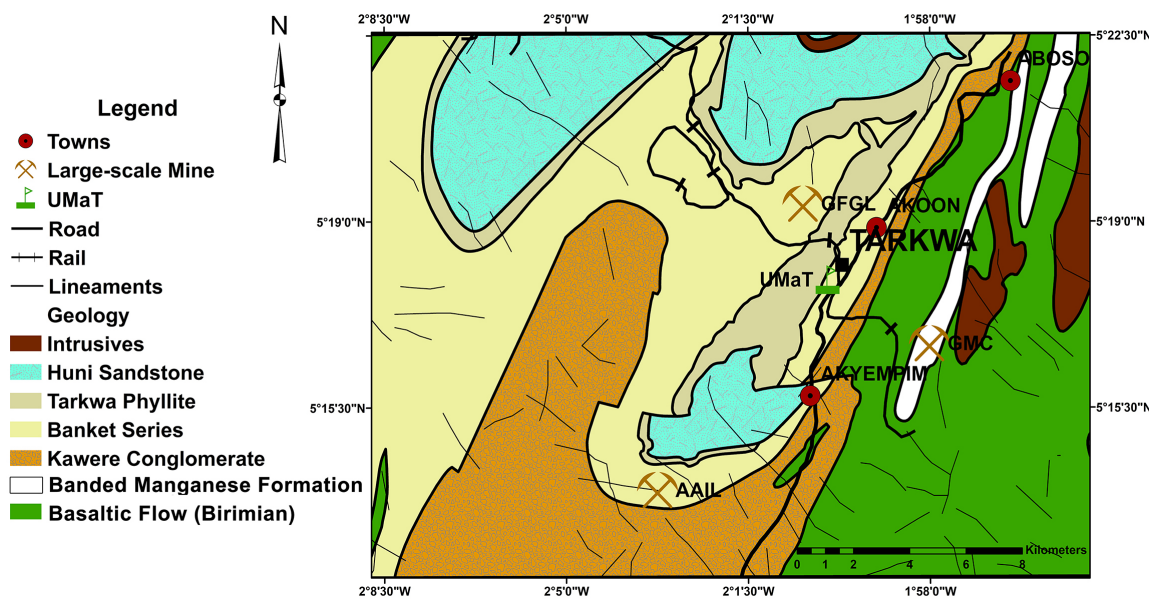

Figure 3. Geological map of Tarkwa area [18].

\section{Materials and Methodology}

\subsection{Desk Study}

A site visit was undertaken to ascertain the current state of the existing open landfill at Aboso. During the visit, the factors such as the topography of the study area, closeness of the landfill to surface waters, settlement and general accessibility of the site were studied.

\subsection{GIS Multi-Criteria Evaluation}

Geographic Information Systems (GIS) has proven to be a useful tool in site selection, thus, over the years many researchers have employed GIS in landfill site selection [34] [35] [36] [37]. Landfill siting is an extremely difficult task to accomplish because the site selection process depends on different factors and regulations [38]. Many of the attributes involved in the process of selection of sanitary landfill sites have a spatial representation, which in the last few years has motivated the predominance of geographical approaches that allow for the integration of multiple attributes using geographic information systems [39]-[44]. The process of assessing these factors involves comparing the actualconditions of the alternative sites with desirable characteristics and is usually referred to as capability/suitability evaluation [45]. The general procedure used by the decision maker to perform suitability analysis using GIS usually entails 1) selecting important factors and defining evaluation criteria, 2) comparing the attributes of the alternative sites on the desirability criteria and generating commensurate suitability values/ratings for each of the factors, 3) aggregating ratings of individual factors into a combined suitability map to identify suitable area(s) [46]. The important factors representing site characteristics under consideration are usually available as attributes of vector or raster layers in a GIS [47]. Each attribute is represented by a criterion map which displays the spatial distribution of an attribute that measures the degree to which its associated objective is achieved [48]. 
Multi-Criteria Evaluation (MCE) is used to deal with the difficulties that decision makers encounter in handling large amounts of complex information [38]. The principle of the method is to divide the decision problems into smaller understandable parts, analyse each part separately, and then integrate the parts in a logical manner [49]. The integration of GIS and MCE is a powerful tool to solve the landfill site selection problem because GIS provide efficient manipulation and presentation of the data and MCE supplies consistent ranking of the potential landfill areas based on a variety of criteria [41]. Higgs [50] reported the potential of integrating multi-criteria techniques with GIS in waste facility location and documented through a review of the existing literature to highlight the opportunities and challenges facing decision makers at different stages of the waste facility management process.

The flow chart in Figure 4 shows the summary of the various stages and procedures which were employed in the selection of a suitable landfill site in Tarkwa. The criteria for the selection of the landfill are given in the Table 1.

Secondary data from Ghana Geological Survey was used for this research. They included boundary, road, surface water, wetlands, railway and built-up areas shapefiles of Tarkwa and its environs. The data was processed using ArcGIS platform. The buffer zones were created based on the concept of proximity using EPA guideline for landfill in Table 1 . The resultant feature class maps

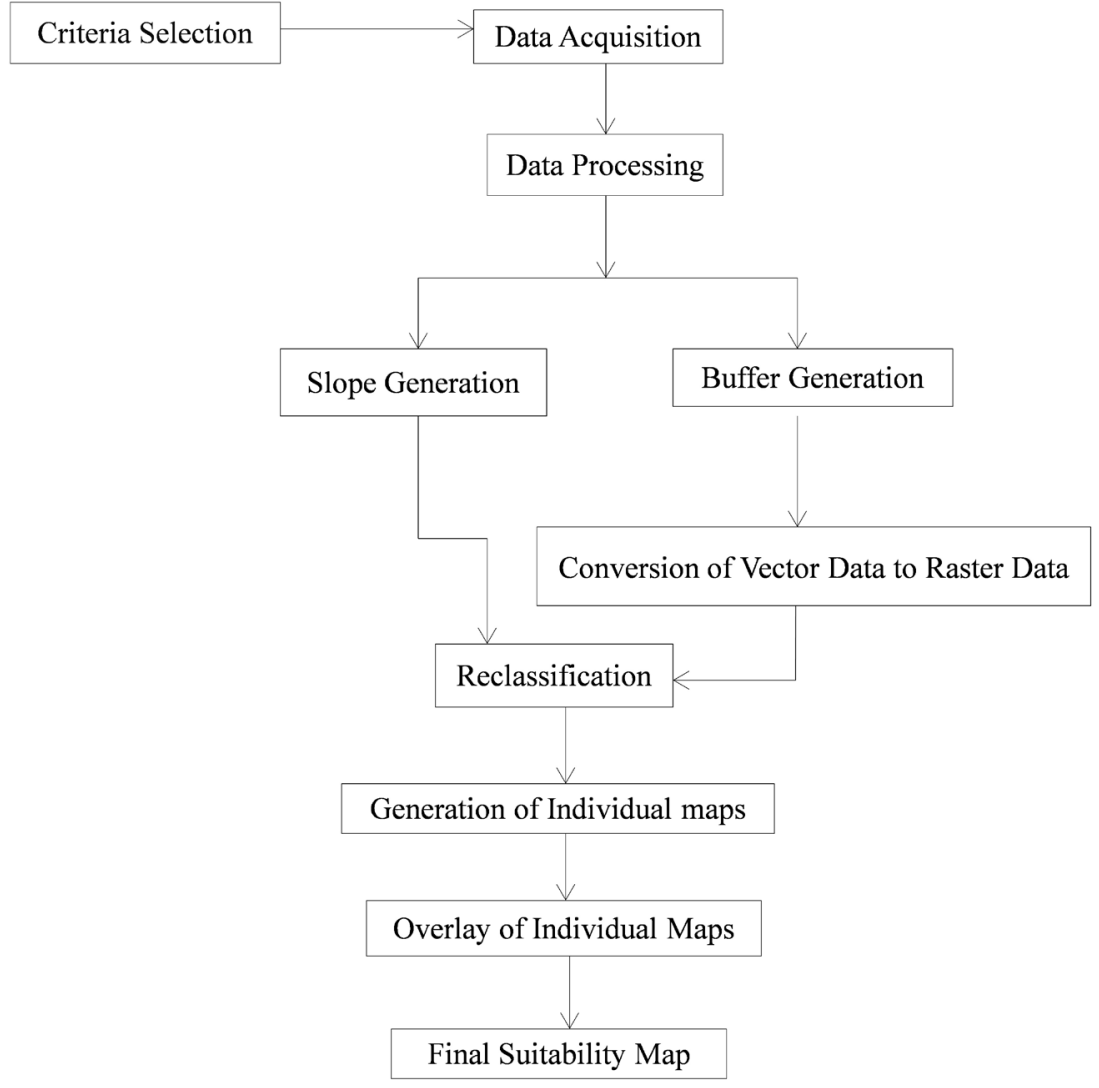

Figure 4. Flowchart for the generation of a landfill suitability map. 
from the buffer generation were vector-based data. The vector-based data were converted to raster-based data before they were reclassified. The binary model approach was used to reclassify all raster-based maps. The Boolean approach was used to the overlay the individual criterion binary maps to generate a final suitability map. The Boolean expression contains two operands and one logical operator. In the expression (Wetlands) $=1$, wetlands and 1 are the operands and " =" is the logic operator. Five expressions $(($ Wetlands $)=1$ (Roads) $=1$ (Railway) $=1($ Built-up areas $)=1$ (Surface water $)=1)$ have been developed from the five criteria considered. In merging the expressions, the Boolean AND connector was used to separate the cells that satisfies suitability.

\subsection{Geophysical Investigation Using Seismic Refraction Tomography}

Seismic-refraction methods measure the time taken for compressional sound wave generated by a sound source to travel down through the subsurface and back up to detectors (geophones) placed on the land surface. The field data acquired consist of measured geophone distances and seismic travel times. From the time-distance information, depths and velocity variations to individual layers can be calculated and modelled [51]. The propagation of seismic (energy) disturbance through a heterogeneous medium is extremely complex although it can be expressed in some equation, where the velocity, travel time, distance can be used to predict the elastic properties of the region through which they pass through [52]. To generate a seismic refraction tomographic model of the subsurface, a tomographic inversion method must be done as stated by [53] [54] [55] [56] [57] after picking the first arrivals and assigning layers to the data.

In the study area, geophysical data was gathered using Geometric ES-3000 Seismodule Controller with a 12-channel seismograph. Four (4) seismic refraction profiles were randomly acquired across the study area. Nine (9) offsets were carried out over each profile line, to have maximum coverage of the subsurface for the tomographic analysis. Stack of three (3) shots were used at various shot locations on a profile to minimize background noise effect and to increase signal to noise ratio. A sampling rate of $62.50 \mu$ s with recording length of $0.25 \mathrm{~s}$ was used. Additionally, a low-cut filter of $15 \mathrm{~Hz}$ was used to filter noise frequency from traffic and a notch filter of $60 \mathrm{~Hz}$ was used to filter frequency noise from power lines.

Data processing started with the picking of the first arrivals using Pickwinsoftware. The next step was to use Plotrefasoftware to assign layers to the various traveltimes. After the layer assignment, an initial velocity model was estimated using Time-term inversion. In this case, two types of inversions, namely time-term inversion and, tomographic inversion, must be performed. The time-term inversion was used to generate the initial velocity model. The depths to the top of the underlying layers are calculated under each point on the traveltime versus offset distance plot. 2D subsurface Seismic Refraction Tomography (SRT) model for the various profiles were generated using tomographic inver- 
sion method.

After the initial velocity model, a tomographic inversion was generated after some number of iterations were completed. After each iteration, ray tracing was initiated. The ray tracing produced a calculated travel time curve. The difference between the calculated and the observed travel times is referred to as the Root Mean Square (RMS) error; the smaller the RMS error, the higher the accuracy of the data. The iterations for the tomographic inversions were stopped when the RMS error reduced to a minimum value, i.e. where further iterations results in no change in the RMS error.

\subsection{Geotechnical Site Investigation}

According to Sukiman [58], the selection of a landfill site put a major concern in the geotechnical site investigation regarding to the fundamental problem in waste disposal sites related with water and soil characteristics in the proposed site. He stressed that aspects to be considered in geotechnical site investigations include hydrology, geology, geochemistry, and engineering properties of soil. Sukiman [58] suggested that for ground investigation up to a depth of $5 \mathrm{~m}$, involving unconsolidated materials, hand auger drill is suitable. Soil engineering properties such as Atterberg' s limit, bulk density, moisture content, particle size and permeability should be determined.

Both field and laboratory tests were undertaken to obtain data for the research. The field work involved visit to the site and sampling. This was followed by laboratory tests to establish the engineering properties of the soil. Laboratory equipment and materials at the soil and rock laboratory of the University of Mines and Technology Tarkwa were used for the laboratory works. These included the Cassagrande apparatus, sieves, wax, mould, hammer, and moisture cans.

The field work involved visits to the study area to take samples for the laboratory work. Other relevant information that was obtained during the field work was the topography and drainage of the area, nature and condition of the soil present. The samples were taken from eight different points (Figure 5) with an interval of $200 \mathrm{~m}$ from each point using an auger drill. Each point was drilled to a depth of $3 \mathrm{~m}$ of which a sample was taken at each meter (a total of (3) three samples were taken from each point), except for point seven where only one-meter sample was taken due to an underneath bed rock. The samples were carefully sealed to prevent loss of some soil properties such as moisture content. Moisture content and bulk density test were conducted for all the sealed samples. Afterwards, the samples were sun dried for two days and the following tests were conducted; particle size analysis, specific gravity, Atterberg limit test andcompaction test. The laboratory test works were conducted according to the British Standards 1377 [59]. The hydraulic conductivity (K) of the soils were calculated from the effective diameter $\left(D_{10}\right)$ values using Hazen [60] empirical formula: 


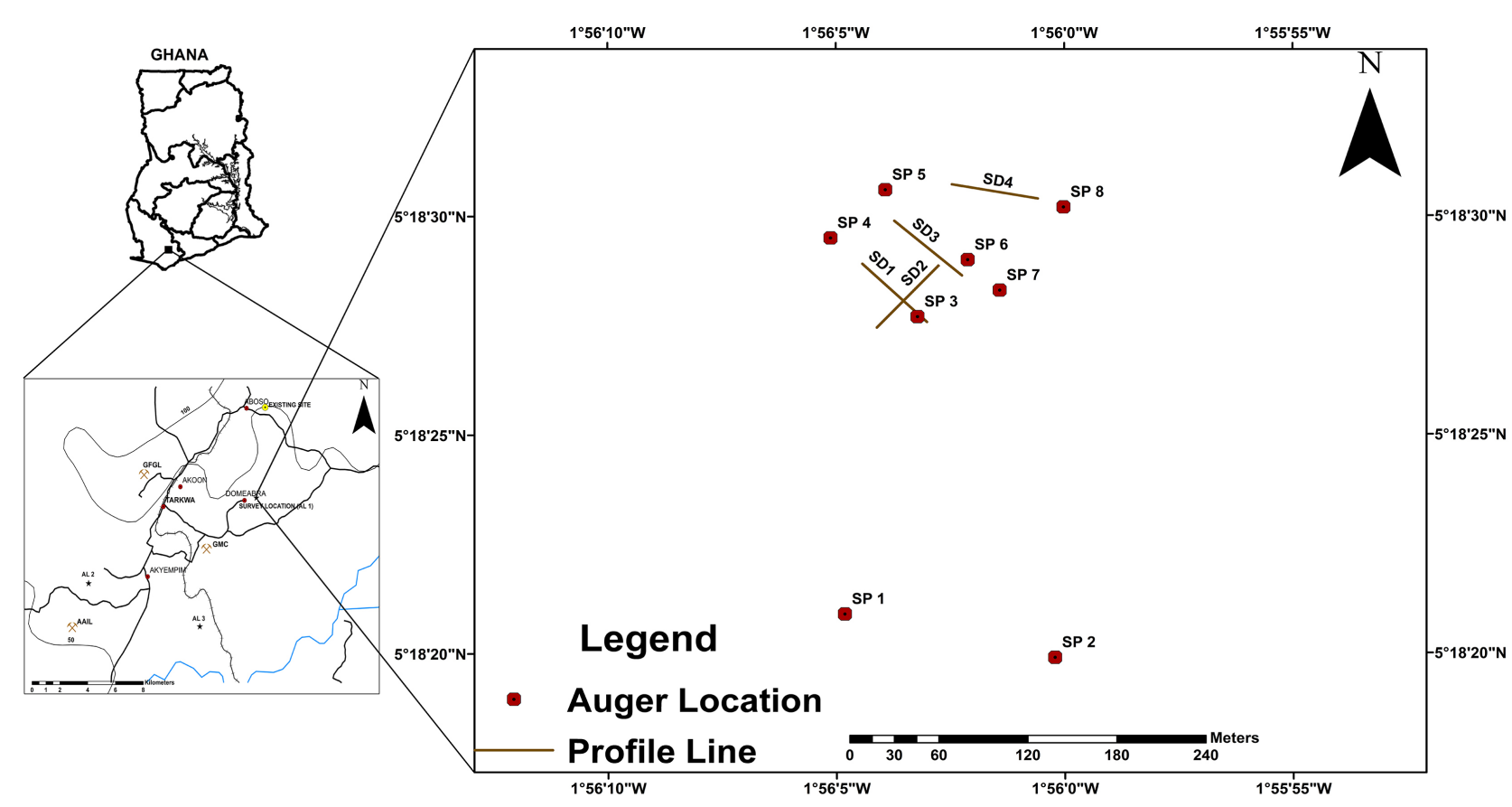

Figure 5. Geotechnical sampling points and seismic refraction survey profile lines.

$$
K=C_{H} *\left(D_{10}\right)^{2}
$$

where:

$C_{H}=$ Empirical constant (0.01157)

$D_{10}=$ the particle size for which $10 \%$ of the material is finer $(\mathrm{mm})$

\section{Results}

\subsection{Landfill Site Selection Using GIS Multi-Criteria Evaluation}

Buffer maps (Figure 6) were generated for wetlands, roads, railway, built-up areas and surface water. The buffer maps serve as constraint maps that restrain unsuitable areas from suitable areas. The Binary model gives two results for each map generated. These results are displayed with two different colour codes with values assigned to them. The colours which have been assigned 1 (true) indicate areas which are suitable for the landfill and the colours which have been assigned 0 (False) indicate areas which are not suitable for the landfill. The resultant Binary maps for the individual criteria considered for the siting of the landfill in the study area are shown in Figure 6.

The final suitability map (Figure 7) shows the suitable areas in blue and unsuitable areas in red after the overlay of individual criterion-based maps.

\subsection{Results of Seismic Refraction Tomography for Domeabra}

The results of the seismic tomographic sections are shown in Figure 8. Inferences about the condition of the subsurface lithology are made from the velocity gradient of the tomographic section. The geological field data of the study 


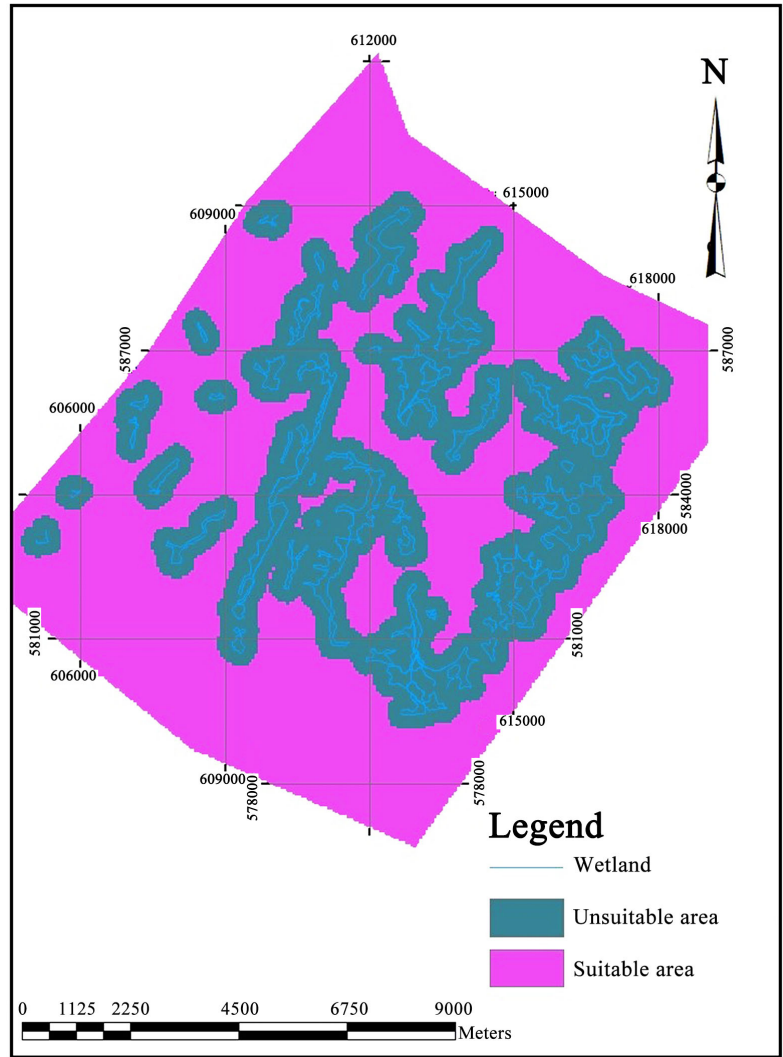

(a)

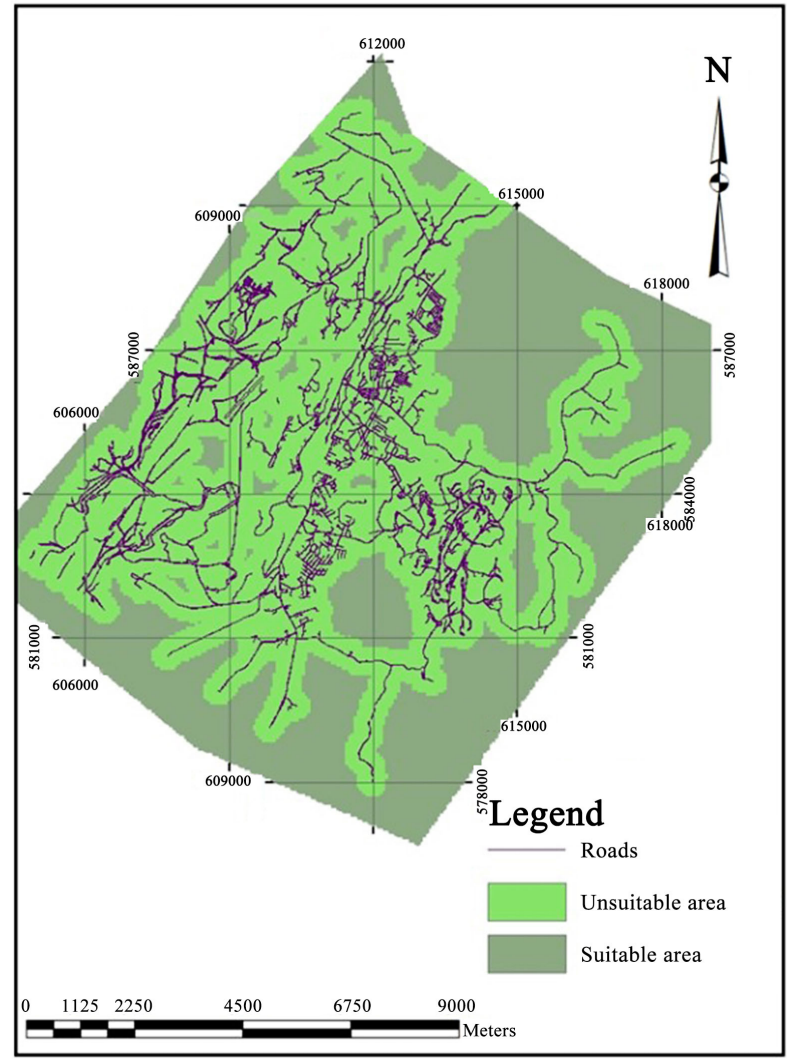

(b) 


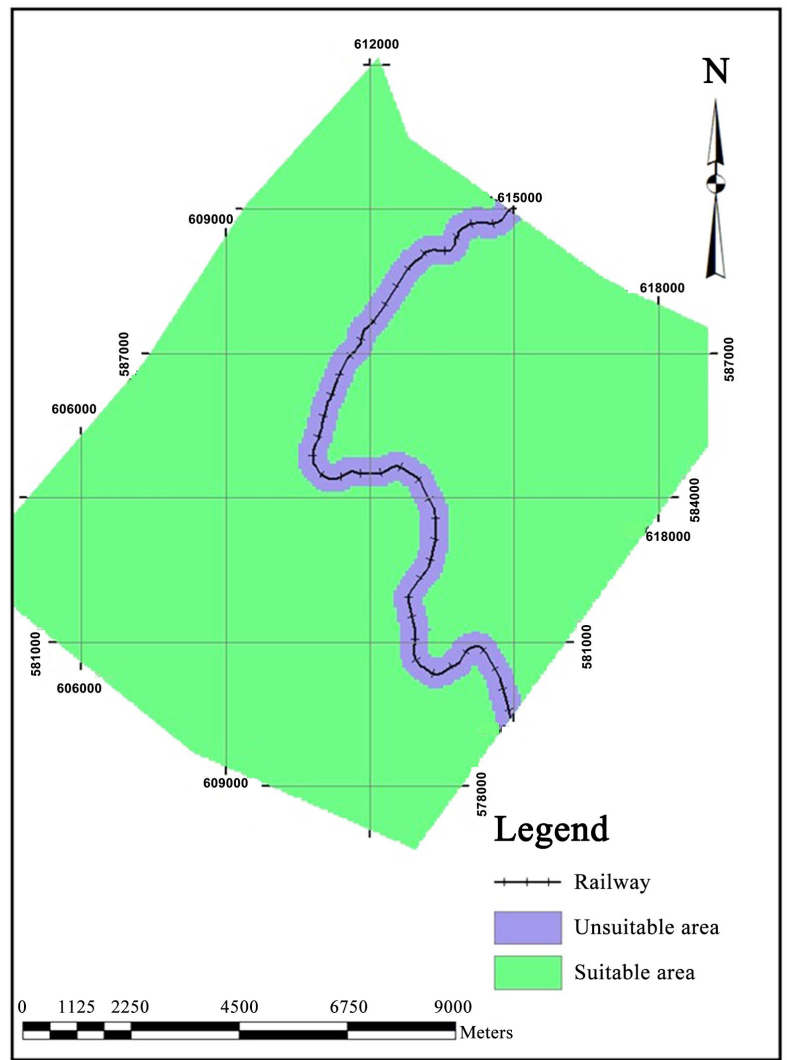

(c)

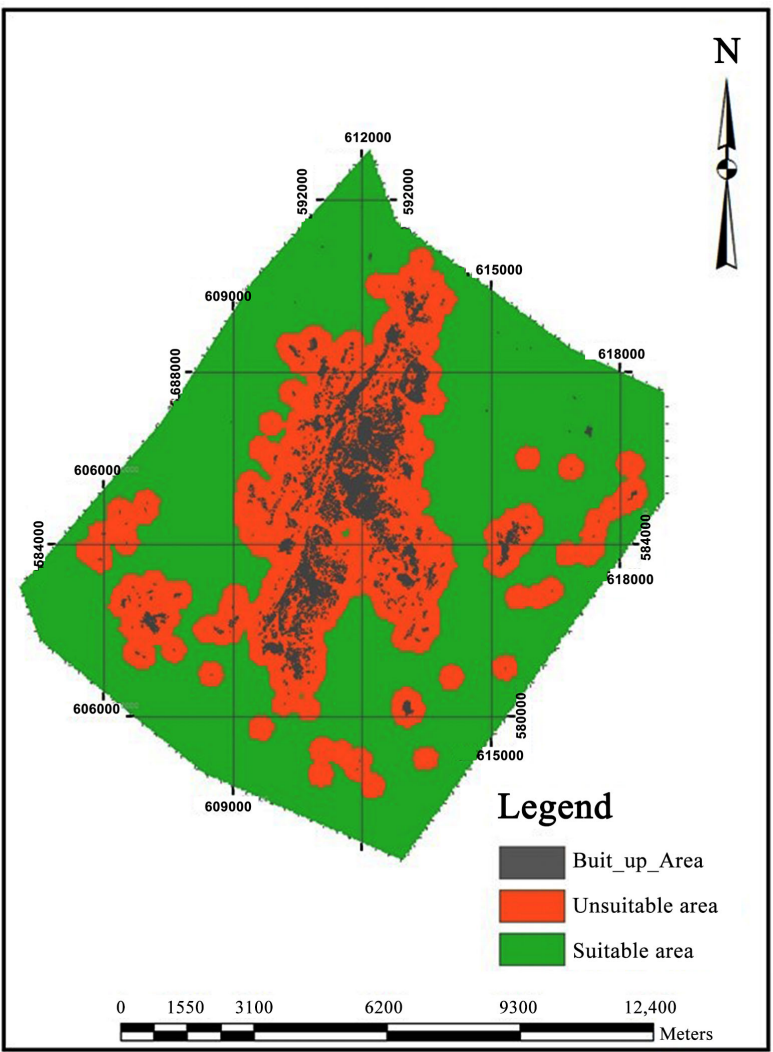

(d) 


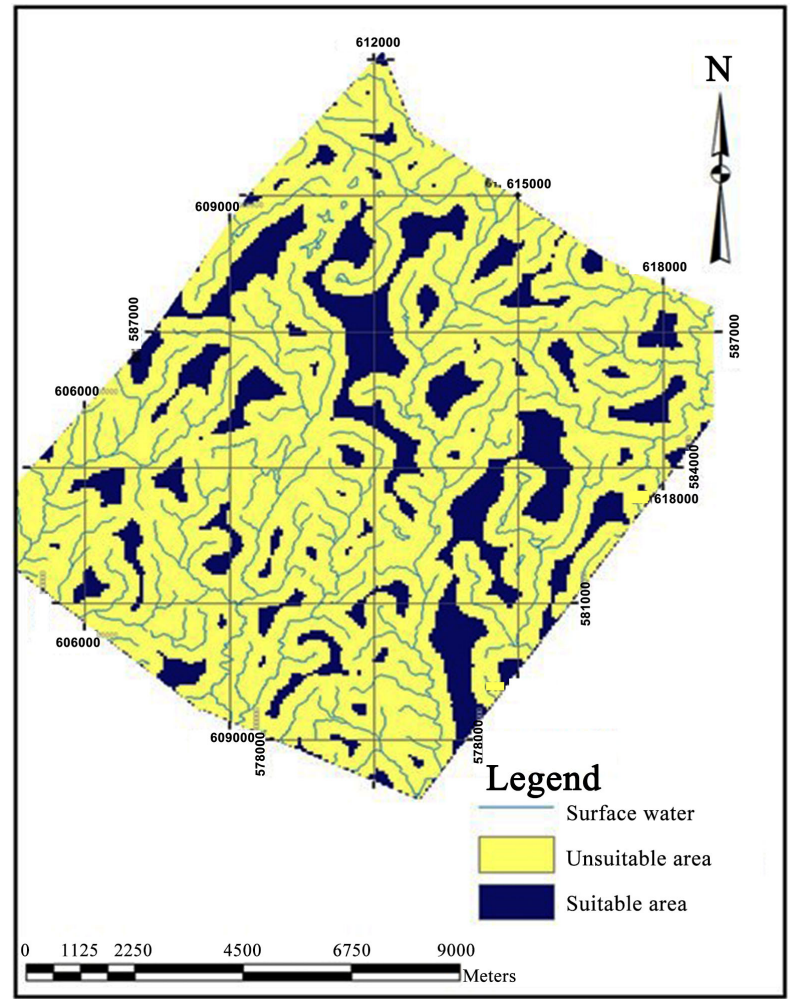

(e)

Figure 6. Binary map of suitable area for landfill based on (a) wetlands (b) roads (c) railway (d) built-up areas and (e) the surface water in Tarkwa area.

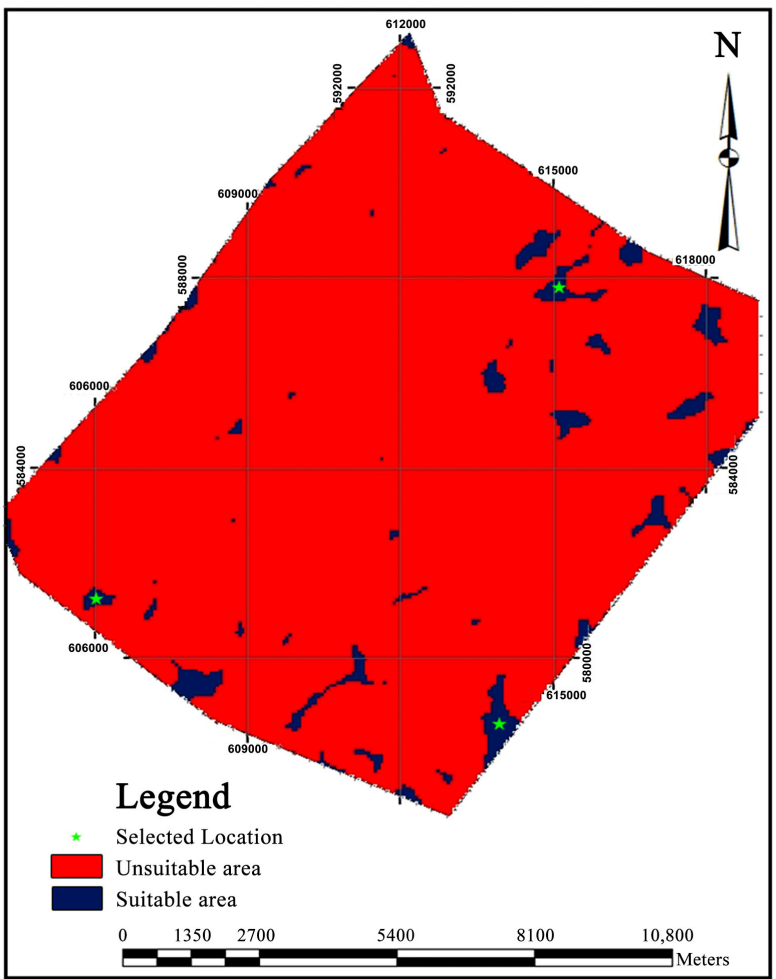

Figure 7. Final map of suitable and unsuitable areas for landfill sites in Tarkwa area. 


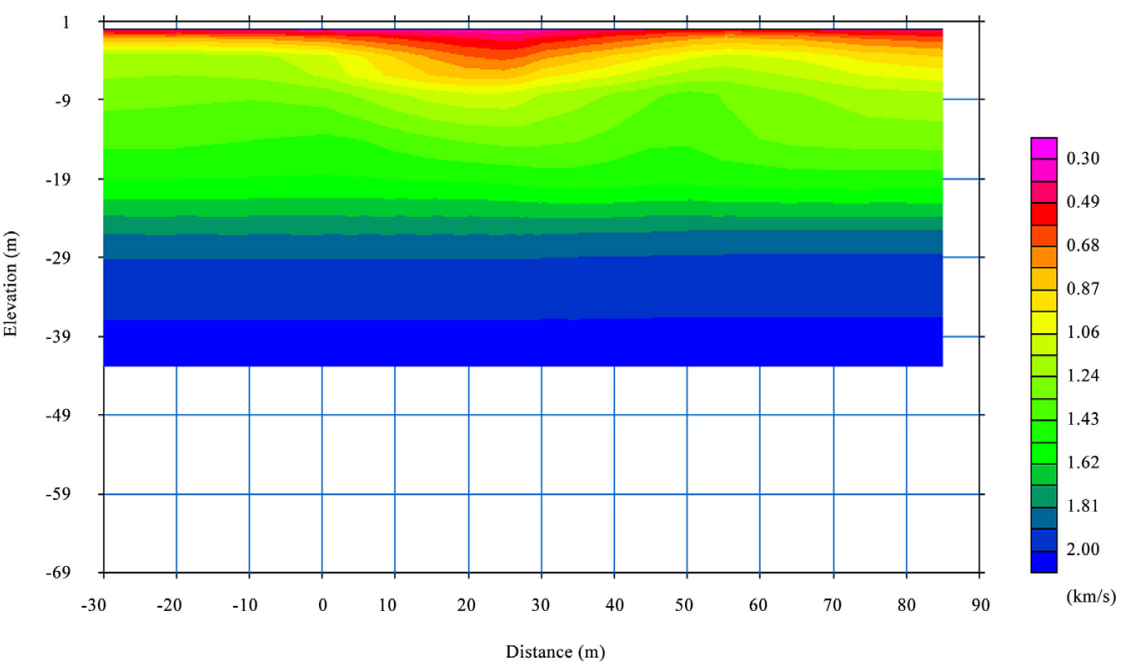

(SD1)

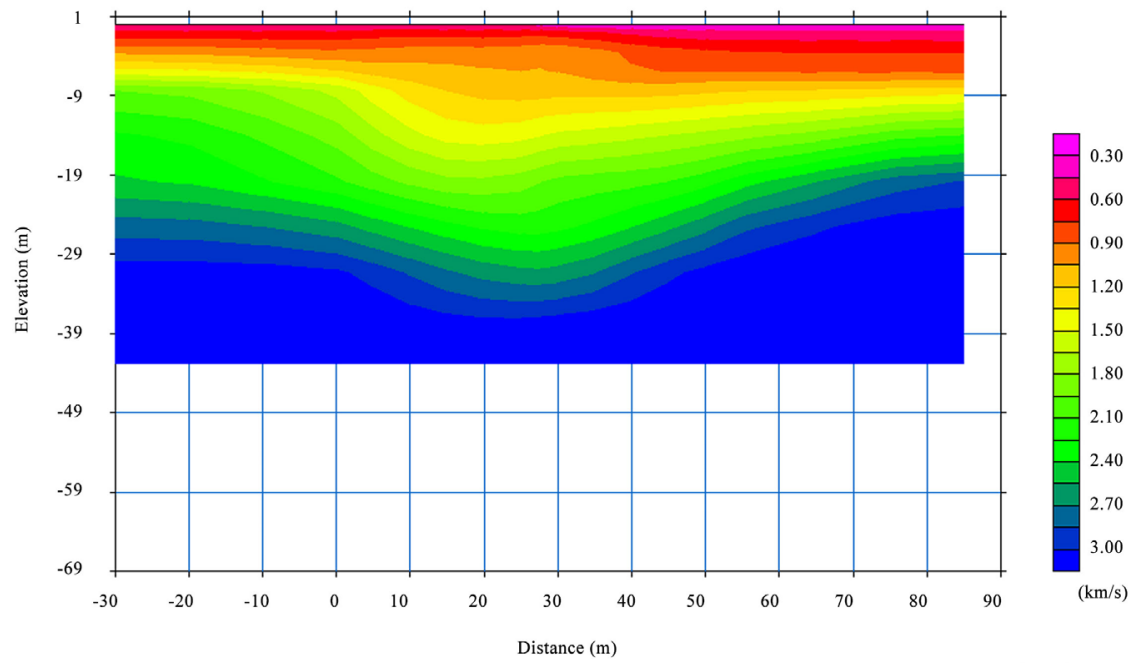

(SD2)

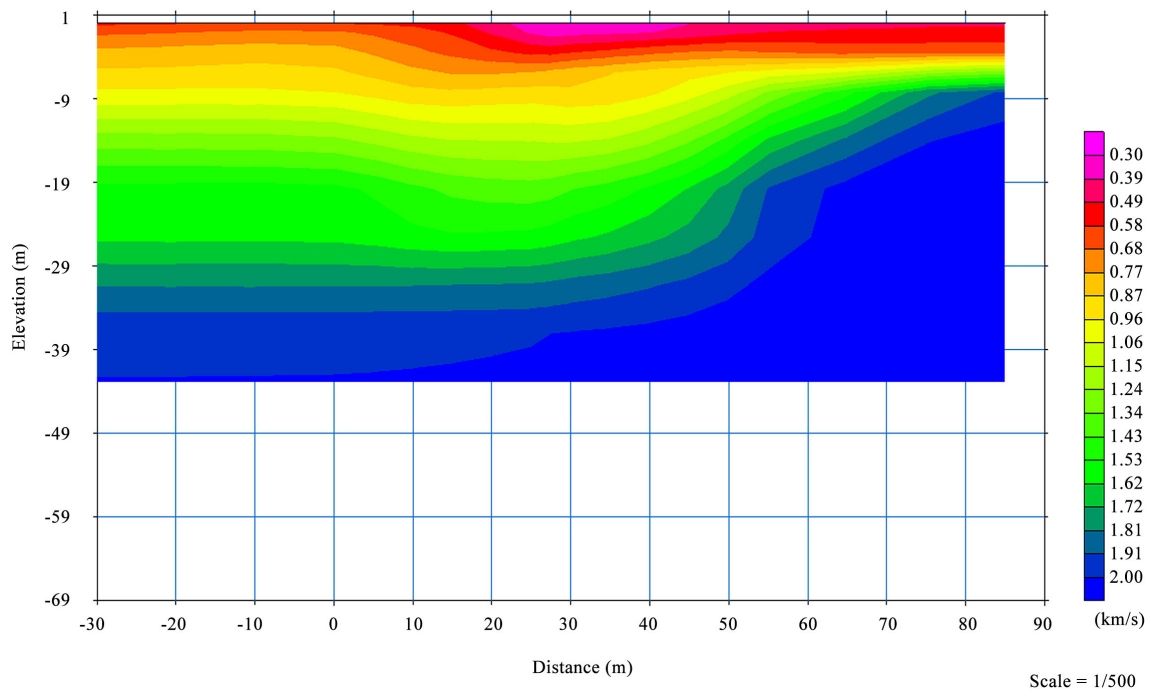

(SD3) 


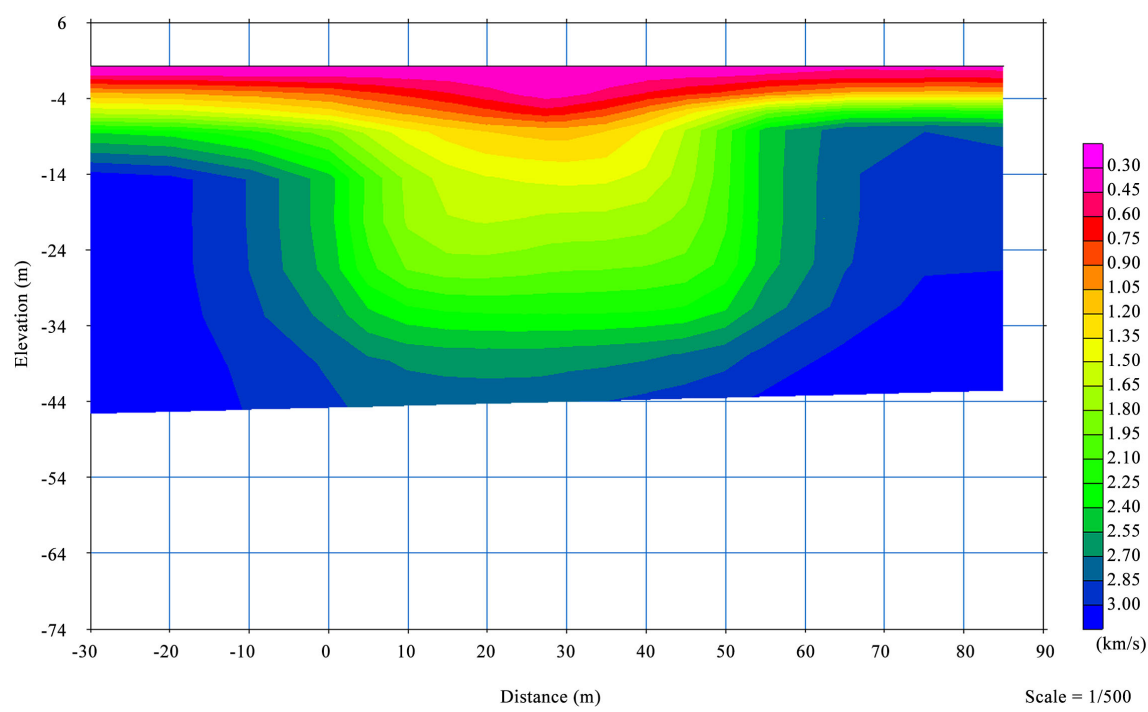

(SD4)

Figure 8. 2D Subsurface Seismic Refraction Tomography (SRT) Models for Profiles SD1 to SD4.

area coupled with the velocity gradient from the tomographic inversion as stated by Raghava et al. [61] aided in the interpretation of the tomographic sections as shown in Table 2 . The velocity models are shown in shades of different colours between pink (low $0.30 \mathrm{~km} / \mathrm{s}$ ) and blue (high $3.0 \mathrm{~km} / \mathrm{s}$ ). The model depicts a velocity distribution that generally increases with depth. The models in Figure 8 are displayed with horizontal distance along the profiles in metres and with a vertical distance which represent the depth of probe measured in metres. The velocities, average thickness and subsurface layer properties for the various profiles (SD1 to SD4) are presented in Table 2.

\subsection{Results of Geotechnical Investigation for Domeabra}

\subsubsection{Natural Moisture Content Test Results}

The moisture content test was conducted for the in-situ soil samples. A known mass of each sample for each hole was oven dried and the dried mass of the samples were determined. The moisture content was determined as follows:

$$
\text { Moisture content }(\%)=(\text { In-situ Mass-Dried Mass }) / \text { Dried Mass }
$$

The average moisture content (Table 3 ) ranges from $11.98 \%$ to $30.72 \%$ for 0 $1 \mathrm{~m}$ depths, $14.36 \%$ to $37.15 \%$ for $1-2 \mathrm{~m}$ depths and $17.44 \%$ to $44.87 \%$ for $2-3$ $\mathrm{m}$ depths.

\subsubsection{Particle Size Analysis}

Table 4 summarises the particle size distribution results for all the samples. The soil is predominantly gravel and sand at depth $0-1 \mathrm{~m}$ with gradual increase in clay and silt content from depth $1-3 \mathrm{~m}$. Uniformity Coefficient $(\mathrm{Cu})$ greater than 5 is dominant except for SP01 $(1.0-2.0 \mathrm{~m})$ and SP02 $(1.0-2.0 \mathrm{~m})$ which has $\mathrm{Cu}$ of 5 typical of well graded soils. SP01 and SP02 $(1.0-2.0 \mathrm{~m})$ are classified 
as uniformly graded soils. Soils with $\mathrm{Cu}$ values greater than 5 , equal to 5 and less than 5 are classified as well graded, uniformly graded and poorly graded soils respectively.

\subsubsection{Specific Gravity}

The specific gravity (Table 5) ranges from $2.38-2.73$ for $0-1 \mathrm{~m}$ depths, 2.29 2.61 for $1-2 \mathrm{~m}$ depths and $2.34-2.85$ for $2-3 \mathrm{~m}$ depths.

\subsubsection{Bulk Density Test}

The bulk density (Table 6) ranges from $1.708 \mathrm{Mg} / \mathrm{m}^{3}$ to $2.452 \mathrm{Mg} / \mathrm{m}^{3}$ and the Dry Density also ranges from $1.398 \mathrm{Mg} / \mathrm{m}^{3}$ to $2.138 \mathrm{Mg} / \mathrm{m}^{3}$.

\subsubsection{Atterberg Test}

The Plastic Index (PI) ranges from $3.49 \%$ to $27.9 \%$, Liquid Limit (LL) from $37.4 \%$ to $59.62 \%$ and PL from $31.6 \%$ to $36.2 \%$ as shown in Table 7 .

\subsubsection{Compaction Test}

The Maximum Dry Density (MDD) ranges from $1.81 \mathrm{~g} / \mathrm{m}^{3}$ to $2.12 \mathrm{~g} / \mathrm{m}^{3}$ for all the samples at depth $2 \mathrm{~m}$ to $3 \mathrm{~m}$ as in Table 8 .

\subsubsection{Hydraulic Conductivity}

The hydraulic conductivity (Table 9) of the area ranges from $0.018 \mathrm{~m} / \mathrm{s}$ to 0.040 $\mathrm{m} / \mathrm{s}$.

\subsection{Discussion of Results}

The multicriteria GIS modelling generated suitable and unsuitable areas for the construction of an engineered landfill. The suitable areas are those which are beyond $500 \mathrm{~m}$ buffer distance and the unsuitable areas below the $500 \mathrm{~m}$ buffer distance. The suitability map (Figure 6) shows fourteen (14) areas within Tarkwa and its environs to be suitable, the Domeabra site was selected because of its proximity to the Tarkwa area.

From the Seismic Refraction Tomography (SRT) analysis, it can be inferred that the subsurface is made up of four layers. The first layer is the top soil with thickness ranging from $0.5 \mathrm{~m}$ to $2 \mathrm{~m}$. The second layer is the weathered or loose material with thickness ranging from $5 \mathrm{~m}$ to $15 \mathrm{~m}$. The third layer is the saturated material with a thickness ranging from $10 \mathrm{~m}$ to $15 \mathrm{~m}$. The fourth layer is the fresh bedrock which is vertically extensive. Figure 9 shows the subsurface profile of the study area with the respective average thicknesses and velocities as interpreted from the SRT models. The analysis reveals that the aquifer is in the third layer with seismic velocities ranging from $1450 \mathrm{~m} / \mathrm{s}$ to $2400 \mathrm{~m} / \mathrm{s}$. The depth to the aquifer ranges from $7 \mathrm{~m}$ to $16 \mathrm{~m}$ whiles the thickness ranges from $10 \mathrm{~m}$ to $15 \mathrm{~m}$.

The moisture content values indicate that the area has good moisture content depicting well drained soils. Das [62], proposed that sandy and gravelly soils may have moisture content of about $15 \%$ to $20 \%$, fine-grained (silty or clayey) 
Table 2. Results obtained from the seismic refraction survey.

\begin{tabular}{cccc}
\hline Profile & Velocity $(\mathrm{m} / \mathrm{s})$ & Average thickness $(\mathrm{m})$ & Layer Description \\
\hline SD 1 & $300-500$ & 0.5 & Dry Sand \\
& $600-1250$ & 15 & Fractured/Loose Material \\
& $1500-2400$ & 10 & Saturated Material \\
& $2700-3000$ & - & Fresh \\
& $300-500$ & 0.5 & Dry Sand \\
& $600-1250$ & 7 & Loose/Fractured Material \\
SD 2 & $1500-2400$ & 12 & Saturated Material \\
& $2700-3000$ & - & Fresh \\
& $300-500$ & 1 & Dry Sand \\
& $600-1250$ & 8 & Saturated Material \\
SD 3 & $1450-1850$ & 10 & Fresh \\
& $2000-3000$ & - & Dry Sand \\
& $300-500$ & 2 & Loose/fractured Material \\
& $600-1250$ & 5 & Saturated Material \\
& $1450-2400$ & 10 & Fresh \\
\hline
\end{tabular}

Table 3. Results of moisture content.

\begin{tabular}{ccc}
\hline Sample ID & Depth $(\mathrm{m})$ & Moisture Content \\
\hline \multirow{2}{*}{ SP01 } & $0.0-1.0$ & 14.36 \\
& $1.0-2.0$ & 16.75 \\
& $2.0-3.0$ & 20.44 \\
SP02 & $0.0-1.0$ & 11.98 \\
& $1.0-2.0$ & 14.36 \\
SP03 & $2.0-3.0$ & 17.44 \\
& $0.0-1.0$ & 13.96 \\
SP04 & $0.0-1.0$ & 12.61 \\
& $1.0-2.0$ & 21.46 \\
SP05 & $2.0-3.0$ & 25.57 \\
& $0.0-1.0$ & 17.15 \\
& $1.0-2.0$ & 22.7 \\
SP06 & $0.0-1.0$ & 21.46 \\
& $1.0-2.0$ & 25.57 \\
& $2.0-3.0$ & 27.82 \\
& $0.0-1.0$ & 18.34 \\
& $1.0-2.0$ & 21.5 \\
& $2.0-3.0$ & 24.31 \\
& $0.0-1.0$ & 30.72 \\
& $1.0-2.0$ & 37.15 \\
\hline
\end{tabular}


Table 4. Results of soil types and particle size distribution.

\begin{tabular}{cccccccc}
\hline Sample ID & Depth & Cu & Grading & \% Gravel & \% Sand & \% Silt & \% Clay \\
\hline \multirow{2}{*}{ SP01 } & $0.0-1.0$ & 6 & Well graded & 30.89 & 64.82 & 3.89 & 0.4 \\
& $1.0-2.0$ & 5 & Uniformly graded & 42.3 & 54.31 & 2.96 & 0.43 \\
& $2.0-3.0$ & 6 & Well graded & 42.33 & 51.13 & 5.94 & 0.6 \\
SP02 & $1.0-2.0$ & 5 & Uniformly graded & 44.1 & 52.13 & 3.6 & 0.17 \\
& $2.0-3.0$ & 6 & Well graded & 38.84 & 54.49 & 2.4 & 4.27 \\
SP04 & $1.0-2.0$ & 6 & Well graded & 36.11 & 61.67 & 2 & 0.22 \\
SP05 & $2.0-3.0$ & 6 & Well graded & 45.36 & 42.87 & 1.9 & 9.87 \\
& $1.0-2.0$ & 6 & Well graded & 37.64 & 59.02 & 3 & 0.34 \\
SP06 & $1.0-2.0$ & 6 & Well graded & 37.64 & 52.4 & 1.66 & 8.3 \\
& $2.0-3.0$ & 6 & Well graded & 47.73 & 37.29 & 4.72 & 10.26 \\
SP07 & $1.0-2.0$ & 6 & Well graded & 36.01 & 53.52 & 0.4 & 10.07 \\
& $2.0-3.0$ & 6 & Well graded & 44.72 & 41.29 & 2.26 & 11.73 \\
SP08 & $1.0-2.0$ & 6 & Well graded & 42.6 & 54.46 & 1.44 & 1.5 \\
& $2.0-3.0$ & 6 & Well graded & 30.5 & 35.13 & 21.8 & 12.57 \\
\hline
\end{tabular}

$\mathrm{Cu}$ is coefficient of uniformity.

Table 5. Results of specific gravity test.

\begin{tabular}{|c|c|c|}
\hline Sample ID & Depth (m) & Average Specific Gravity \\
\hline \multirow{3}{*}{ SP01 } & $0.0-1.0$ & 2.51 \\
\hline & $1.0-2.0$ & 2.41 \\
\hline & $2.0-3.0$ & 2.6 \\
\hline \multirow{3}{*}{ SP02 } & $0.0-1.0$ & 2.41 \\
\hline & $1.0-2.0$ & 2.29 \\
\hline & $2.0-3.0$ & 2.67 \\
\hline \multirow[t]{2}{*}{ SP03 } & $0.0-1.0$ & 2.4 \\
\hline & $0.0-1.0$ & 2.41 \\
\hline \multirow[t]{2}{*}{ SP04 } & $1.0-2.0$ & 2.61 \\
\hline & $2.0-3.0$ & 2.85 \\
\hline \multirow{2}{*}{ SP05 } & $0.0-1.0$ & 2.38 \\
\hline & $1.0-2.0$ & 2.5 \\
\hline \multirow{3}{*}{ SP06 } & $0.0-1.0$ & 2.85 \\
\hline & $1.0-2.0$ & 2.52 \\
\hline & $2.0-3.0$ & 2.34 \\
\hline \multirow{3}{*}{ SP07 } & $0.0-1.0$ & 2.73 \\
\hline & $1.0-2.0$ & 2.44 \\
\hline & $2.0-3.0$ & 2.43 \\
\hline \multirow{3}{*}{ SP08 } & $0.0-1.0$ & 2.53 \\
\hline & $1.0-2.0$ & 2.4 \\
\hline & $2.0-3.0$ & 2.38 \\
\hline
\end{tabular}


Table 6. Results of bulk density and dry density test.

\begin{tabular}{|c|c|c|c|}
\hline Sample ID & Depth (m) & Bulk Density $\left(\mathrm{Mg} / \mathrm{m}^{3}\right)$ & Dry Density $\left(\mathrm{Mg} / \mathrm{m}^{3}\right)$ \\
\hline \multirow{3}{*}{ SP01 } & $0.0-1.0$ & 2.015 & 2.004 \\
\hline & $1.0-2.0$ & 2.286 & 2.036 \\
\hline & $2.0-3.0$ & 1.868 & 1.633 \\
\hline \multirow{3}{*}{ SP02 } & $0.0-1.0$ & 2 & 1.986 \\
\hline & $1.0-2.0$ & 2.15 & 2.138 \\
\hline & $2.0-3.0$ & 2.452 & 2.072 \\
\hline \multirow[t]{2}{*}{ SP03 } & $0.0-1.0$ & 1.862 & 1.654 \\
\hline & $0.0-1.0$ & 2.219 & 1.872 \\
\hline \multirow[t]{2}{*}{ SP04 } & $1.0-2.0$ & 2.232 & 2.001 \\
\hline & $2.0-3.0$ & 2.44 & 2.112 \\
\hline \multirow{2}{*}{ SP05 } & $0.0-1.0$ & 2.085 & 2.075 \\
\hline & $1.0-2.0$ & 2.404 & 2.102 \\
\hline \multirow{3}{*}{ SP06 } & $0.0-1.0$ & 2.327 & 1.826 \\
\hline & $1.0-2.0$ & 2.219 & 1.826 \\
\hline & $2.0-3.0$ & 1.708 & 1.398 \\
\hline \multirow{3}{*}{ SP07 } & $0.0-1.0$ & 2.204 & 1.883 \\
\hline & $1.0-2.0$ & 2 & 1.986 \\
\hline & $2.0-3.0$ & 2.016 & 2 \\
\hline \multirow{3}{*}{ SP08 } & $0.0-1.0$ & 1.956 & 1.594 \\
\hline & $1.0-2.0$ & 2.05 & 1.495 \\
\hline & $2.0-3.0$ & 2.052 & 1.416 \\
\hline
\end{tabular}

Table 7. Results of Liquid Limits (LL), Plastic Limits (PL) and Plastic Index (PI).

\begin{tabular}{ccccc}
\hline Sample ID & Depth (m) & Liquid Limit \% & Plastic Limit \% & Plastic Index \% \\
\hline \multirow{2}{*}{ SP01 } & $1.0-2.0$ & 38.94 & 34.9 & 4.04 \\
& $2.0-3.0$ & 49.7 & 35.1 & 14.6 \\
SP02 & $1.0-2.0$ & 37.4 & 33.91 & 3.49 \\
& $2.0-3.0$ & 46.21 & 33.97 & 12.24 \\
SP04 & $1.0-2.0$ & 35.95 & 31.6 & 4.35 \\
SP05 & $2.0-3.0$ & 46.27 & 36.9 & 9.37 \\
SP06 & $1.0-2.0$ & 39.2 & 33.6 & 5.6 \\
& $1.0-2.0$ & 42.92 & 31.9 & 11.02 \\
SP07 & $2.0-3.0$ & 48.39 & 30.6 & 17.79 \\
& $1.0-2.0$ & 51.92 & 36.2 & 15.72 \\
SP08 & $2.0-3.0$ & 59.62 & 32.5 & 27.12 \\
& $1.0-2.0$ & 42 & 33.54 & 8.46 \\
\hline
\end{tabular}


Table 8. Summary of results for compaction test for the various samples.

\begin{tabular}{cccc}
\hline Sample ID & $\begin{array}{c}\text { Depth } \\
(\mathrm{m})\end{array}$ & $\begin{array}{c}\text { Maximum Dry Density } \\
(\mathrm{MDD})\left(\mathrm{g} / \mathrm{m}^{3}\right)\end{array}$ & $\begin{array}{c}\text { Optimum Moisture Content } \\
(\mathrm{OMC})(\%)\end{array}$ \\
\hline \multirow{2}{*}{ SP01 } & $1.0-2.0$ & 1.98 & 21.7 \\
& $2.0-3.0$ & 2.11 & 15.5 \\
SP02 & $1.0-2.0$ & 1.99 & 22.16 \\
SP05 & $2.0-3.0$ & 2.12 & 16.6 \\
SP06 & $1.0-2.0$ & 2.15 & 17 \\
& $1.0-2.0$ & 2.01 & 15.62 \\
SP07 & $2.0-3.0$ & 1.95 & 21.34 \\
& $1.0-2.0$ & 1.96 & 19.73 \\
SP08 & $2.0-3.0$ & 1.86 & 22.99 \\
\hline
\end{tabular}

Table 9. Summary of hydraulic conductivity values.

\begin{tabular}{cccccc}
\hline Sample ID & Depth $(\mathrm{m})$ & $\mathrm{D}_{60}$ & $\mathrm{D}_{10}$ & $\mathrm{C}_{\mathrm{U}}$ & Hydraulic Conductivity $(\mathrm{m} / \mathrm{s})$ \\
\hline \multirow{3}{*}{ SP01 } & $0.0-1.0$ & 1.5 & 0.25 & 6 & 0.026 \\
& $1.0-2.0$ & 1.25 & 0.25 & 5 & 0.018 \\
& $2.0-3.0$ & 1.6 & 0.29 & 6 & 0.030 \\
SP02 & $1.0-2.0$ & 1.55 & 0.29 & 5 & 0.028 \\
& $2.0-3.0$ & 1.6 & 0.25 & 6 & 0.030 \\
SP04 & $1.0-2.0$ & 1.65 & 0.29 & 6 & 0.031 \\
SP05 & $2.0-3.0$ & 1.7 & 0.3 & 6 & 0.033 \\
SP06 & $1.0-2.0$ & 1.85 & 0.29 & 6 & 0.040 \\
& $1.0-2.0$ & 1.55 & 0.25 & 6 & 0.028 \\
SP07 & $2.0-3.0$ & 1.75 & 0.3 & 6 & 0.035 \\
& $1.0-2.0$ & 1.6 & 0.25 & 6 & 0.030 \\
SP08 & $2.0-3.0$ & 1.4 & 0.25 & 6 & 0.023 \\
& $1.0-2.0$ & 1.6 & 0.29 & 6 & 0.030 \\
\hline
\end{tabular}

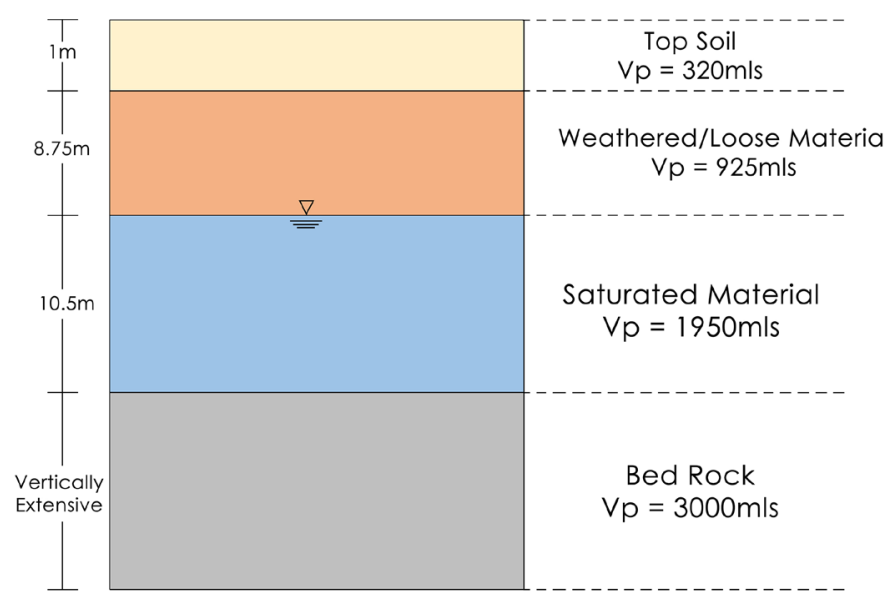

Figure 9. Subsurface profile of study area from the Seismic Refraction Tomography (SRT) analysis. 
soils may also have moisture content up to about $50 \%$ to $80 \%$. The soils in the proposed area have varying proportion of gravel and sand with low proportion of fine grains at $0-1 \mathrm{~m}$ depth. Higher values of moisture content are obtained at $1-2 \mathrm{~m}$ depth as that of fine-grained soils.

Specific gravity values from Table 5 depicts the usual values of soils suitable for landfill construction. Soils which have specific gravity values less than 2 are organic in nature and they may not be suitable for landfill site construction. The values from Table 6 fall within the usual bulk density and dry density values for soils. The samples with high clay content exhibit high bulk density but low dry density due to their ability to hold more water. The clay content in the area, thus, increases with increasing depth.

The plasticity and plasticity index of the various samples increases with depth due to the increasing clay content with depth (Table 7). According to Marcin et al. [63], clay materials of high plasticity index approximately greater than $30 \%$, allow very good sealing capabilities but show high shrinkage potentials. They also show horizontal deformation during shrinkage as well as susceptibility for desiccation, triggering the increase in permeability and are unable to regain their initial hydraulic conductivity after rewetting. Usually recommended soil properties to achieve hydraulic permeabilities of order $10^{-9} \mathrm{~m} / \mathrm{s}$ by compaction are: percentage of fines $(<0.075 \mathrm{~mm}) \geq 30 \%$, plasticity index between 20 and 30 and percentage of gravel (5 to $50 \mathrm{~mm}$ ) $\leq 20 \%$ [64]. The soils at depth $2.0-3.0 \mathrm{~m}$ has high clay content and high plasticity. However, the total percentage fines for all the samples is less than 15 and are not good lining materials.

Compacting soils at the study area at water contents above $25.01 \%$ will result in a relatively dispersed soil structure that is weaker, more ductile, less pervious, softer, less susceptible to swelling and more susceptible to shrinking. Conversely, when the soil on the proposed landfill site is compacted at a water content lower than $25.01 \%$, it will result in a flocculated soil structure with random orientation that has opposite characteristics of when it is compacted wet at the optimum water content. The samples with high clay content exhibit low MDD values with high OMC whiles samples with low clay content exhibits high MDD values with low OMC values. The hydraulic conductivity values of the in-situ soils are greater than $10^{-9} \mathrm{~m} / \mathrm{s}$ proposed by Roehl et al. [64]. The soils at the proposed area at Domeabra should be compacted to achieve the required hydraulic conductivity. This will increase the residence time for leachates to interact with the clay liner thereby degrading the leachate plume.

\section{Conclusions}

The following conclusions can be made:

- The existing site at Aboso is not suitable for the construction of an engineered landfill due to high water table, leachate runoff to nearby stream, presence of structural deformation and proximity to build up areas.

- The multicriteria GIS modelling identified fourteen (14) suitable areas for the 
siting of landfill in the Tarkwa area. A site located in Domeabra was chosen due to its proximity to the neighboring communities of Tarkwa, Nsuta and Aboso.

- The geophysical survey showed that the proposed site at Domeabra is made up of four layers. The first layer is the top soil with thickness ranging from $0.5 \mathrm{~m}$ to $2 \mathrm{~m}$. The second layer is the weathered material with thickness ranging from $5 \mathrm{~m}$ to $15 \mathrm{~m}$. The third layer is the saturated material with thickness ranging from $10 \mathrm{~m}$ to $15 \mathrm{~m}$. The fourth layer is the fresh rock which is vertically extensive.

- The water table occurs at a depth of 12 to $15 \mathrm{~m}$ which falls within the acceptable limits for landfill construction.

- The soil at the proposed site is predominantly gravel and sand, well graded with gradual increase in clay content with depth and has a good moisture content. The gravel and sandy soils have good to excellent shear strength and workability.

- The proposed area has good dry density, bulk density and specific gravity soil.

- The plasticity and plasticity index of the proposed area increases with depth due to the increasing clay content, however the soil is not a good lining material due to the high percentage of gravel.

- The evaluated geophysical and geotechnical properties of the proposed area in Domeabrais suitable for the construction of an engineered landfill site.

- The multicriteria GIS modelling has proven to be an accurate tool for landfill site selection.

\section{Recommendations}

The following recommendations are being made for consideration:

- Soil chemical test should be performed.

- Detailed geological and structural mapping should be conducted.

- The socio-economic impact of the proposed project should be evaluated.

\section{Acknowledgements}

The Authors would like to acknowledge Mr Osei Agyemang Jnr for his support during the ArcGIS modelling in 2014. Thanks to Mr David Amoah for his assistance during the assessment of existing open landfill at Aboso in 2017. The Authors appreciate Mr Osei Mensah Bonsu Isaac for his effort during the geotechnical site investigation at the proposed site at Domeabra in 2018.

\section{Conflicts of Interest}

The authors declare no conflicts of interest regarding the publication of this paper.

\section{References}

[1] Sankoh, F.P., Yan, X. and Tran, Q. (2013) Environmental and Health Impact of 
Solid Waste Disposal in Developing Cities: A Case Study of Granville Brook Dumpsite, Freetown, Sierra Leone. Journal of Environmental Protection, 4, 665. https://doi.org/10.4236/jep.2013.47076

[2] Tian, H., Gao, J., Hao, J., Lu,L., Zhu, C. and Qiu, P. (2013) Atmospheric Pollution Problems and Control Proposals Associated with Solid Waste Management in China: A Review. Journal of Hazardous Materials, 252-253, 142-154. https://doi.org/10.1016/j.jhazmat.2013.02.013

[3] Talyan, V., Dahiya, R.P. and Sreekrishnan, T.R. (2008) State of Municipal Solid Waste Management in Delhi, the Capital of India. Journal of Waste Management, 28, 1276-1287. https://doi.org/10.1016/j.wasman.2007.05.017

[4] Owusu-Sekyere, E., Bagah, D.A. and Quansah, J.Y.D. (2015) The Urban Solid Waste Management Conundrum in Ghana: Will It Ever End? World Environment, 5, 52-62.

[5] Oteng-Ababio, M. (2013) Unscripted (In)justice: Unequal Exposure to Ecological Hazards in Metropolitan Accra. Journal of Environment and Planning A, 45.

[6] Ghosh, S.K. (2016) Sustainable SWM in Developing Countries Focusing on Faster Growing Economies, India and China. Procedia Environmental Sciences, 35, 176-184. https://doi.org/10.1016/j.proenv.2016.07.073

[7] Singh, R.P., Tyagi, V.V., Allen, T., Ibrahim, M.H. and Kothar, R. (2011) An Overview for Exploring the Possibilities of Energy Generation from Municipal Solid Waste (MSW) in Indian Scenario. Renewable and Sustainable Energy Reviews, 15, 4797-4808. https://doi.org/10.1016/j.rser.2011.07.071

[8] Aatamila, M., Verkasalo, P.K., Korhonen, M.J., Viluksela, M.K., Pasanen, K., Tiittanen, P. and Nevalainen, A. (2010) Odor Annoyance near Waste Treatment Centres: A Population-Based Study in Finland. Journal of Air and Waste Management Association, 60, 412-418. https://doi.org/10.3155/1047-3289.60.4.412

[9] Giusti, L. (2009) A Review of Waste Management Practices and Their Impact on Human Health. Waste Management, 29, 2227-2239.

https://doi.org/10.1016/j.wasman.2009.03.028

[10] Nwanta, J.A. and Ezenduka, E. (2010) Analysis of Nsukka Metropolitan Abattoir Solid Waste in South Eastern Nigeria: Public Health Implications. Archives of Environmental and Occupational Health, 65, 21-26. https://doi.org/10.1080/19338240903390263

[11] Xiao, Y., Bai, X., Ouyang, Z., Zheng, H. and Xing, F. (2007) The Composition, Trend and Impact of Urban Solid Waste in Beijing. Environmental Monitoring and Assessment, 135, 21-30. https://doi.org/10.1007/s10661-007-9708-0

[12] Yongsi, H.B.N., Herrmann, T.M., Ntetu, A.L., Sietchiping, R. and Bryant., C. (2008) Environmental Sanitation and Health Risks in Tropical Urban Settings: Case study of Household Refuse and Diarrhea in Yaoundé-Cameroon. International Journal of Human And Social Sciences, 3, 220-228.

[13] UN-HABITAT (2010) Solid Waste Management in the World's Cities. UNHABITAT, Nairobi.

[14] Kusi, E., Nyarko, A.K., Boamah, L.A. and Nyamekye, C. (2016) Landfills: Investigating Its Operational Practices in Ghana. International Journal of Energy and Environmental Science, 1, 19-28.

[15] Onibokum, A.G. and Kumuyi, A.J. (1999) Governance and Waste Management in Africa. In: Onibokun, A.G., Ed., Managing the Monster. Urban Waste and Governance in Africa, International Development Research Center Canada. 
[16] MLGRD (Ministry of Local Government and Rural Development) (2010) Environmental Sanitation Policy (Revised 2010). Government of Ghana.

[17] EPA (2002) Ghana Landfill Guidelines. Environmental Protection Agency, Accra, 81.

[18] Ghana Geological Survey (2009) Geological Map of Ghana-1:1,000,000. Geological Survey Department, Accra.

[19] Kortatsi, B.K. (2004) Hydrochemistry of Groundwater in the Mining Area of Tarkwa-Prestea, Ghana. PhD Thesis Report, University of Ghana, Accra, 132 p.

[20] Attoh, K., Evans, M.J. and Bickford, M.E. (2006) Geochemistry of an Ultramafic-Rodingite Rock Association in the Paleoproterozoic Dixcove Greenstone Belt, Southwestern Ghana. Journal of African Earth Sciences, 45, 333-346. https://doi.org/10.1016/j.jafrearsci.2006.03.010

[21] Bessoles, B. (1977) Geologie de l'Afrigue, Vol. 1. Craton de l' OuestAfricain. Bur. De Rech. Min. Mem 88, 402.

[22] Doumbia, S., Pouclet, A., Kouamelan, A., Peucat, J.J., Vidal, M. and Delor, C. (1998) Petrogenesis of Juvenile-Type Birimian (Palaeoproterozoic) Granitoids in Central Côte d'Ivoire, West Africa: Geochemistry and Geochronology. Precambrian Research, 87, 33-63. https://doi.org/10.1016/S0301-9268(97)00201-5

[23] Boher, M., Abouchami, W., Michard, A., Albarède, F. and Arndt, N.T. (1992) Crustal Growth in West Africa at 2.1 Ga. Journal of Geophysical Research, 97, 345-369. https://doi.org/10.1029/91JB01640

[24] Kesse, G.O. (1985) The Mineral and Rock Resources of Ghana. A. A. Balkema, Rotterdam, 610 .

[25] Junner, N.R., Hirst, T. and Service, H. (1942) The Tarkwa Goldfield. Gold Coast Geological Survey, Memoir No. 6, 48-55.

[26] Kitson, A.E. (1928) Provisional Geological Map of the Gold Coast and Western Togoland, with Brief Notes Thereon. Gold Coast Geological Survey Bulletin, No. 2, 13.

[27] Milesi, J.P., Ledru, P., Dommanget, A., Johan, V. and Diallo, M. (1989) Lower Proterozoic Succession in Senegal and Mali (West Africa): Position of Sediment-Hosted $\mathrm{Au}$ and Fe Deposits of Loulo Area and Significance in Terms of Crustal Evolution. 28 th International Geological Congress, Washington DC, 433-434.

[28] Leube, A., Hirdes, W., Mauer, R. and Kesse, G.O. (1990) The Early Proterozoic Birimian Supergroup of Ghana and Its Associated Gold Mineralisation. Precambrian Research, 46, 139-165. https://doi.org/10.1016/0301-9268(90)90070-7

[29] Pouclet, A., Vidal, M., Delor, C., Simeon, Y. and Alric, G. (1996) Le volcanismebirimien de la Cote d'Ivoire, mise enévidence de deux phases volcano tectoniquesdistinctes dans l'évolutiongéodynamique du Paléoprotéroïque. Bulletin de la Société géologique de France, 167, 529-541.

[30] Milesi, J.-P., Ledru, P., Feybessee, J.L., Dommanget, A. and Marcoux, E. (1992) Early Proterozoic Ore Deposits and Tectonics of the Birimian Orogenic Belt, West Africa. Precambrian Research, 58, 305. https://doi.org/10.1016/0301-9268(92)90123-6

[31] Kortatsi, B.K. (2002) Hydrochemistry of Groundwater in the Mining Area of Tarwa Prestea, Ghana. PhD Thesis, University of Ghana, Accra, 70-85.

[32] Kuma, J.S. (2007) Hydrogeological Studies in the Tarkwa Gold Mining District, Ghana. Bulletin of Engineering Geology and the Environment, 66, 89-99. 
https://doi.org/10.1007/s10064-006-0048-Z

[33] Dapaah-Siakwan, S. and Gyau-Boakye, P. (2000) Hydrogeologic Framework and Borehole Yields in Ghana. Hydrogeology Journal, 8, 405-416.

https://doi.org/10.1007/PL00010976

[34] Khamehchiyan, M., Nikoudel, M.R. and Boroumandi, M. (2011) Identification of Hazardous Waste Landfill Site: A Case Study from Zanjan Province, Iran. Environmental Earth Sciences, 64, 1763-1776. https://doi.org/10.1007/s12665-011-1023-y

[35] Donevska, K.R., Gorsevski, P.V., Jovanvski, M. and Pesevski, I. (2012) Regional Non-Hazardous Landfill Site Selection by Integrating Fuzzy Logic, AHP and Geographic Information Systems. Environmental Earth Sciences, 67, 121-131. https://doi.org/10.1007/s12665-011-1485-y

[36] Nazari, A., Salarirad, M.M. and Bazzazi, A.A. (2012) Landfill Site Selection by Decision-Making-Tools Based on Fuzzy Multi-Attribute Decision Making Method. Environmental Earth Sciences, 65, 1631-1642. https://doi.org/10.1007/s12665-011-1137-2

[37] Sahnoun, H., Serbaji, M.N., Karray, B. and Medhioub, K. (2012) GIS and Multi-Criteria Analysis to Select Potential Sites of Agro-Industrial Complex. Environmental Earth Sciences, 8, 2477-2489. https://doi.org/10.1007/s12665-011-1471-4

[38] Nas, B., Cay, T., Iscan, F. and Berktay, A. (2010) Selection of MSW Landfill Site for Konya, Turkey Using GIS and Multi-Criteria Evaluation. Environmental Monitoring and Assessment, 160, 491. https://doi.org/10.1007/s10661-008-0713-8

[39] Kontos, T.D., Komilis, D.P. and Halvadakis, C.P. (2003) Siting MSW Landfills on Lesvos Island with a GIS-Based Methodology. Waste Management and Research, 21, 262-277. https://doi.org/10.1177/0734242X0302100310

[40] Sarptas, H., Alpaslan, N. and Dolgen, D. (2005) GIS Supported Solid Waste Management in Coastal Areas. Water Science and Technology, 51, 213-220.

https://doi.org/10.2166/wst.2005.0408

[41] Sener, B., Suzen, L. and Doyuran, V. (2006) Landfill Site Selection by Using Geographic Information Systems. Environmental Geology, 49, 376-388. https://doi.org/10.1007/s00254-005-0075-2

[42] Gomez-Delgado, M. and Tarantola, S. (2006) Global Sensitivity Analysis, GIS and Multi-Criteria Evaluation for a Sustainable Planning of a Hazardous Waste Disposal Site in Spain. International Journal of Geographical Information Science, 20, 449-466. https://doi.org/10.1080/13658810600607709

[43] Delgado, O.B., Mendoza, M., Granados, E.L. and Geneletti, D. (2008) Analysis of Land Suitability for the Siting of Inter-Municipal Landfills in the Cuitzeo Lake Basin, Mexico. Waste Management, 28, 1137-1146. https://doi.org/10.1016/j.wasman.2007.07.002

[44] Chang, N., Parvathinathanb, G. and Breden, J.B. (2008) Combining GIS with Fuzzy Multicriteria Decision Making for Landfill Siting in a Fast-Growing Urban Region. Journal of Environmental Management, 87, 139-153. https://doi.org/10.1016/j.jenvman.2007.01.011

[45] Stoms, D.M., McDonald, J.M. and Davis, F.W. (2002) Fuzzy Assessment of Land Suitability for Scientific Research Reserves. Environmental Management, 29, 545-558. https://doi.org/10.1007/s00267-001-0004-4

[46] Malczewski, J. (2002) Fuzzy Screening for Land Suitability Analysis. Geographical and Environmental Modelling, 6, 27-39. 
https://doi.org/10.1080/13615930220127279

[47] Qiu, F., Chastain, B., Zhou, Y., Zhang, C. and Sridharan, H. (2013) Modeling Land Suitability/Capability Using Fuzzy Evaluation. GeoJournal, 79, 167-182.

[48] Malczewski, J. (1999) GIS and Multicriteria Decision Analysis. Wiley, New York, 392.

[49] Malczewski, J. (1997) Propagation of Errors in Multicriteria Location Analysis: A Case Study. In: Fandel, G. and Gal, T., Eds., Multiple Criteria Decision Making, Springer, Berlin, 154-155. https://doi.org/10.1007/978-3-642-59132-7_17

[50] Higgs, G. (2006) Integrating Multi-Criteria Techniques with Geographical Information Systems in Waste Facility Location to Enhance Public Participation. Waste Management \& Research, 24, 105-117. https://doi.org/10.1177/0734242X06063817

[51] Haeni, F.B. (1988) Application of Seismic Refraction Technique to Hydrologic Studies. United States Government Printing Office, Washington DC, 95.

[52] Leucci, G., Greco, F., De Giorgi, L. and Mauceri, R. (2007) Three-Dimensional Image of Seismic Refraction Tomography and Electrical Resistivity Tomography Survey in the Castle of Occhiola (Sicily, Italy). Journal of Archaeological Science, 34, 233-242. https://doi.org/10.1016/j.jas.2006.04.010

[53] Boschetti, F., Dentith, M.C. and List, R.D. (1996) Inversion of Seismic Refraction Data Using Genetic Algorithms. Geophysics, 61, 1715-1727. https://doi.org/10.1190/1.1444089

[54] Schuster, G.T. and Quintus-Bosz, A. (1993) Wavepath Eikonal Traveltime Inversion: Theory. Geophysics, 58, 1314-1323. https://doi.org/10.1190/1.1443514

[55] Sheehan, J.R., Doll, W.E. and Mandell, W.A. (2005) An Evaluation of Methods and Available Software for Seismic Refraction Tomography Analysis. Journal of Environmental \& Engineering Geophysics, 10, 21-34. https://doi.org/10.2113/JEEG10.1.21

[56] Wright, C. (2006) The LSDARC Method of Seismic Refraction Analysis: Principles, Practical Considerations and Advantages. Near Surface Geophysics, 4, 189-202.

[57] Zhang, J. and Toksöz, M.N. (1998) Nonlinear Refraction Traveltime Tomography. Geophysics, 63, 1726-1737. https://doi.org/10.1190/1.1444468

[58] Sukiman, N. (2006) Geotechnical Site Selection and Investigation for Landfill Site.

[59] British Standard (2004) 1377 (1990) Methods of Test for Soils for Civil Engineering Purposes. British Standards Institution, London.

[60] Hazen, A. (1911) Discussion of "Dams on Sand Foundations" by A. C. Koenig. Transactions of the American Society of Civil Engineers, 73, 199-203.

[61] Raghava, M.V., Jawahar, G. and Sherbakova, T.V. (1977) An Ultrasonic Profiling Investigation on Some Fresh and Weathered Granites of Hyderabad, India. Geophysical Prospecting, 25, 768-779. https://doi.org/10.1111/j.1365-2478.1977.tb01203.x

[62] Das, B.M. (2002) Soil Mechanics Laboratory Manual. Oxford University Press, New York, 6th Edition, 8-9.

[63] Marcin, K.W., Witol, S. and Anna, M. (2018) Clays of Different Plasticity as Materials for Landfill Liners in Rural Systems of Sustainable Waste Management. Sustainability, 10, 2489.

[64] Roehl, K.E., Alamgir, M., Razzaque, M.A. and Sarkar, G. (2009) Geoenvironmental Properties of Clays for Landfill Construction in Bangladesh. International Conference on Solid Waste Management and Waste Safe, Vol. 2, Khulna, 9-10 November 2009, 503-511. 